\title{
Third-Party Logistics (3PL) and Supply Chain Performance in the Chinese Market: A Conceptual Framework
}

\author{
Huilan Zhang ${ }^{1} \&$ Sam C. Okoroafo ${ }^{1}$ \\ ${ }^{1}$ College of Business and Innovation, The University of Toledo, Toledo, OH, USA \\ Correspondence: Huilan Zhang, College of Business and Innovation, The University of Toledo, Toledo, OH, \\ 43606, USA. E-mail: Huilan.Zhang@rockets.utoledo.edu
}

Received: June 24, 2014

Accepted: August 21, $2014 \quad$ Online Published: April 27, 2015

doi:10.5539/emr.v4n1p38

URL: http://dx.doi.org/10.5539/emr.v4n1p38

\begin{abstract}
Supply chains are becoming more international and sophisticated. With the globalization of businesses, competition between enterprises has evolved to competition between supply chains. The development of third party logistics (3PL) service can help supply chain to achieve cost reduction and shorten lead time simultaneously. For this reason, third party logistics has been integrated into supply chain to enhance supply chain performance. However, we notice that not only is the research on China's 3PL still in its infancy, but also the role of 3PL in supply chain is not well examined from the Chinese market perspective. The intent of this study is to fill the void by providing a framework addressing how to leverage third-party logistics to improve supply chain performance in the Chinese market. The intended contribution of this study is that we hope our research constitutes a pioneer study that conceptually addresses the relationship between 3PL and supply chain performance, upon which data from the Chinese market can be tested.
\end{abstract}

Keywords: third-party logistics, 3PL, logistics flexibility, supply chain participant, supply chain performance

\section{Introduction}

One of the most significant consequences of globalization is that supply chains are becoming more international and sophisticated. With the globalization of businesses, competition between enterprises has evolved to competition between supply chains. While faced with severe competition, supply chain which can deliver products quickly and on-time through the support of a logistics system has higher probability to survive. However, historically, it seemed that supply chains cannot pursue cost reduction and shorten lead time simultaneously as evidenced by the fact that the logistics costs were a big part of the cost of the supply chain. During the last two decades, a remarkable development in the global supply chain network helped solve this dilemma. The new development has been the emergence of third party logistics (3PL), the philosophy under which is that companies can achieve cost reduction and on-time delivery by outsourcing logistics services with 3PL providers. A 3PL provider can fulfill the demands for advanced logistics services, in the field of transportation, warehousing, freight consolidation and distribution, inventory management, cross docking, product returns, order management, and logistics information systems (Rabinovich, Windle, Dresner, \& Corsi, 1999). The core competitive advantage of a 3PL provider comes from its ability to integrate those logistics services to help its customers manage their whole distribution systems (Wang \& Sang, 2005). Given that 3PL providers connect the suppliers, manufacturers, and the retailers in supply chains and provide product movement as well as logistics information flow through the supply chain, 3PL providers play a crucial role in managing entire supply chain and thus have great potential to improve the performance of the supply chain.

This present study aims to provide a conceptual framework for 3PL providers in the Chinese market for several reasons. Firstly, China has established a reputation in the last two decades as the "world's workshop". Manufacturers in China purchase raw materials, components, subassemblies, and packaging materials from upstream suppliers and distribute the huge amount of products to the downstream customers. Suppliers and customers are located nationwide or worldwide. The movement of the physical materials and products needs an effective logistics management. A case in point is the BMW operation in China. The BMW group requires a distribution facility that could provide easy access to the Pearl River Delta area in China. For this reason, the BMW group hired Hutchison Logistics, a third-party logistics provider in China; the latter operates a facility as a regional distribution center for BMW, shipping automobile parts throughout the Pearl River Delta area. Secondly, 
China has become a coveted market due to tremendous economic growth as well as large number of consumers in the world. The Chinese consumers are shopping worldwide for the same cars, fashions and electronic must-haves as their counterparts in North America and Europe. Hopefully, they can get the various commodities in a timely manner. To this end, the in-bound and out-bound physical production flows cannot be fulfilled seamlessly in the absence of 3PLs. Thirdly, it is worth noting that although China's logistics industry has grown very quickly in recent years, along with China's high economic growth of $10 \%$ annually during the past decade, limited research has focused on 3PL providers in the Chinese market (Huo, Selen, Yeung, \& Zhao, 2008; Zhao, Flynn, \& Roth, 2007). However, not only is the research on China's 3PL still in its infancy (Lau \& Wang, 2009; Wang, Chu, Zhou, \& Lai, 2008; Zhao et al., 2007), but also the role of 3PL in supply chainis not well examined from Chinese market perspective (Chu \& Wang, 2012).

The intent of this study is to fill the void by providing a framework addressing how to leverage third-party logistics to improve supply chain performance in the Chinese market. The intended contribution of this study is that we hope our research constitutes a pioneer study that conceptually addresses the relationship between 3PL and supply chain performance, upon which data from the Chinese market can be tested. In addition, this study focuses on the relationship between 3PL providers and users, and discusses how their interactions help to increase logistics flexibility, which in turn increases the supply chain performance.

The remainder of the paper is organized as follows. In section 2, we review the relevant literature. In section 3, we discuss the conceptual framework. We conclude with a discussion of intended contributions and directions for future research in section 4 .

\section{Literature Review}

\subsection{Third-Party Logistics and Its Integration in Supply Chain}

There is no consistent definition for third party logistics. According to Berglund, van Laarhove, Sharman, and Wandel (1999), third party logistics refers to "activities carried out by a logistics service provider on behalf of a shipper and consisting of at least management and execution of transportation and warehousing. In addition, other activities can be included, for example inventory management, information related activities, such as tracking and tracing, value added activities, such as secondary assembly and installation of products, or even supply chain management". They also notice that contract is required to "contain some management, analytical or design activities, and the length of the cooperation between shipper and provider to be at least one year, to distinguish third-party logistics from traditional 'arm's length' sourcing of transportation and/or warehousing". For the purpose of this study, we utilize this definition as it emphasizes the role of third party logistics provider in supply chain. It is noted that "logistics outsourcing" and "contracted logistics" are often used more or less interchangeably as "third party logistics".

Increasingly, 3PL providers are integrated into supply chains (Jayaram \& Tan, 2010; Tezuka, 2011; Chu \& Wang, 2012) because 3PL helps to manage the entire supply chain. Tezuka (2011) also highlights that supply chain participants may enjoy advantages derived from four contributory sources of 3PL specialization: scale, know-how, searching ability, and IT skills. Under the context of the supply chain, 3PL providers interact with suppliers, manufacturers, and retailers to provide various logistics service to them.

\subsection{Potential Risk}

According to Risk Theory, risk means the uncertainty that will affect the realization of organization objectives (Cheng \& Yu, 2010). Supply chain disruptions happened in the past few years have turned the spotlight on supply chain risk identification and management. The risks involved in the whole supply chain include but not limited to supply risks, operational risks, demand risks, security risks, informational risks, relational risks, and logistics risks (Cavinato, 2004; Manuj \& Mentzer, 2008). To avoid taking on some risks, shippers including suppliers and manufacturers delegate logistics operations to 3PL providers (Tezuka, 2011). In this study, we focus on the logistics; therefore, we discuss the logistics risks faced by 3PL providers in the supply chain, which admits that 3PL providers may not deliver the expected level of service. Other risks are out of the scope of this study. We define the potential risk as a situation where 3PL providers will suffer potential losses. The dimensions of potential risk that we believe are most commonly faced by the 3PL providers under supply chain context are weather risk, information transmission risk, and cooperation risk.

The first potential risk is the weather risk, including risks related to floods, tornadoes, hurricanes, earthquakes, and other natural disasters (Oke \& Gopalakrishnan, 2009). For instance, the Wenchuan earthquake broke out in China in 2008 prevented relevant supplies to reach stores on time, thus rendered stores to be unavailable in the regions affected by the earthquake. Products manufactured in Wenchuan area either were destroyed or could not 
be delivered to other regions of China. If 3PL providers don't have access to the accurate weather forecast, they have to make plans proactively to avoid or mitigate the potential lost, or the supply chain will suffer disruptions and tremendous loss. According to $23^{\text {rd }}$ Annual R. Hadly Water Supply Chain Symposium, in 2011 alone, the National Weather Bureau estimated that weather related conditions caused \$14 billion in damages which does not include the supply chain related costs due to delays and emergency shipments.

The second potential risk is information transmission risk. In line with Cavinato's informational risk (2004), we refer information transmission risk to the risk caused by asymmetric information or distorted information between the 3PL provider and other supply chain participants (i.e., suppliers, manufacturers and retailers). The 3PL providers have taken on not only traditional distribution activities, such as warehousing and transportation operations, but also managerial activities related to the flow of goods, as well as certain production activities (Fabbe-Costes, Jahre, \& Roussat, 2009). A well-functioning information transmission mechanism is required to ensure the information about goods flow to every supply chain partner; otherwise the decision making will be based on asymmetric or distorted information.

The third potential risk is cooperation risk, which caused by problems of cooperation between the 3PL provider and other supply chain participants. In recent years, the relationship quality between 3PL providers and other supply chain participants have grown in importance (Chu \& Wang, 2012) because 3PL providers deal with the movement of products between different participants in the supply chain (Nagarajan, Savitskie, Ranganathan, Sen, \& Alexandrov, 2013). If other participants don't cooperate with 3PL providers in a timely manner, then all supply chain participants including 3PL providers will suffer losses in terms of time and cost.

\subsection{Information Technology Investment}

The investment and successful implementation of IT is a means to enhance logistics competitiveness (Lai, Li, Wang, \& Zhao, 2008; Wang, Lai, \& Zhao, 2008). In this study, we define information technology investment as 3PL providers' investment in information technology with an attempt to integrate the flow of information between 3PL providers and other supply chain participants.

Bowersox, Daugherty, Droge, Rogers, and Wardlow (1989) note that the "ability and willingness to invest in state-of-the-art IT" is one of the ten key differentiators between leading-edge logistics organizations and average firms. The Global Logistics Research Team at Michigan State University (1995) indicates that IT represents one of the crucial capabilities that combine logistics process integration and world-class performance. An integrated IT system also has been identified as a key component of the extended enterprise model developed by Bowersox and Daugherty (1995), and Bowersox, Closs, and Stank (1999). In a highly competitive context, characterized by "time compression", effective leadership of logistics service providers lies in their capacity to innovate in the area of joint flows management. More specifically, 3PL providers must maintain very close ties to technologies, particularly information technology (Sauvage, 2003). Today's highly competitive business environment makes high level IT investment more important than ever. 3PL providers invest in various information technologies such as GPS, RFID, bar coding, Electronic Data Interchange, and supply chain planning, etc. (Zheng, Fu, \& Yang, 2012; Third-Party Logistics Study, 2014). For example, the real time guidance provided by the GPS technology can help improve JIT service in supply chain; therefore, reduce cost associated with inventory management. Another case is the weather forecasting technology. Savvy businesses are investing in weather prediction technology with an attempt to make logistical decisions (Markowitz, 2011). By investing in this information technology, 3PL providers could utilize long range weather analytics based upon the historical seasonal shipping patterns and determine if there is additional risk due to the natural disasters.

On the other hand, other supply chain participants could utilize information technology invested by 3PL providers to streamline activities throughout the whole supply chain. For instance, Interorganizational Information Systems (IOS), invested by 3PL providers, can facilitate communications among participants within the supply chain (Lewis \& Talalayevsky, 2000; Lai et al., 2008). The long range weather forecasts provided by the weather forecasting information technology can be entered into the suppliers demand planning process to forecast specific product demand.

However, it is worth pointing out that some companies have invested in IT but their collaborative practices did not improve a lot. Holweg, Disney, Holmström, and Småros (2005) argue that although some information technologies such as Vendor Managed Inventory (VMI) and Collaborative Planning, Forecasting and replenishment (CPFR) initiatives benefit supply chain partners, lack of common understanding of these concepts and the difficulty of integrating external collaboration with internal production and inventory control will lead to slow progress of IT implementation.IN deed, in practice, some IT implementations are a failure in terms of meeting their objectives of flexibility, responsiveness, reliability, and quality. Companies could spend more than 
$\$ 1$ million on a given IT system, just to scrap it in the end. Synthesizing the literature, Bharadwaj (2000) argues that it is how firms leverage their investments rather than IT per se to create unique IT resources and skills that determine a firm's overall effectiveness. We therefore argue that it is not the IT itself but the way IT is used that brings some painful things to the company; it is not the IT per se but the way IT is integrated into operations that brings benefits to the company. We still focus on IT investment throughout the paper, since IT investment is the prerequisite for IT implementation.

\subsection{Integrated Logistics Relationship}

Logistics deals with the movement of products between different participants in the supply chain, thus a crucial question in logistics is the issue of integration between participants in the supply chain (Panayides \& So, 2005). Panayides and So (2005) also suggest that all the parties in a supply chain, including 3PL provider and their clients, should work in a collaborative manner in an effort to share and receive information and improve overall quality. As suggested by the late Robert V. Delaney, relationships are what will carry the logistics industry into the future (Third-party logistics, 2007, p. 18). In supply chain, suppliers, manufacturers, and retailers rely upon the third party logistics providers to offer logistics services designed to meet their specific needs. To do so, third party logistics providers have to interact with other supply chain participants on joint problem solving, planning processes, and continuous improvement efforts. In this study, we define integrated logistics relationship as trust and collaboration between 3PL providers and other supply chain participants. By engaging in integrated logistics relationships, the suppliers, manufacturers, retailers, and 3PL providers communicate on a regular basis to make rational inventory management and distribution plans, and work on solving joint problems as well. The integrated logistics relationship supplies resources and assets that any single party in the supply chain may not have. This relationship can also satisfy customer expectations and save on logistics costs (Chu \& Wang, 2012).

\subsection{Logistics Flexibility}

"Flexibility" is not uniformly defined within the literature (Golden \& Powell, 2000). In the supply chain literature, flexibility is considered as the ability of the supply chain to adapt to the changes (Angerhofer \& Angelides, 2006). Logistics flexibility has been identified as key component of supply chain flexibility (Duclos, Vokurka, \& Lummus, 2003; Kumar, Shankar, \& Yadav, 2007; Kumar, Shankar, \& Yadav, 2008; Choy et al, 2008; Nagarajan et al., 2013) due to the reason that logistics is a key operational function enabling the flow of materials and resource between suppliers and customers (Naim, Aryee, \& Potter, 2010). Duclos et al. (2003) define logistics flexibility as the ability to cost effectively receive and deliver product as sources of supply and customers change. Kumar et al. (2008) define logistics flexibility as the ability to control the flow and storage of raw materials, finished goods, services, and related information from origin to destination in response to changing environmental conditions. For the purpose of this paper, we adopt the definition as given by Kumar et al. (2008) because they are able to identify key components of logistics flexibility under uncertainty.

\subsection{Supply Chain Performance}

Many supply chain performance measurements have been proposed including sales growth, cost reduction, lead time, customer satisfaction, forecast accuracy, etc. (Angerhofer \& Angelides, 2006; Ramanathan, Gunasekaran, \& Subramanian, 2011). These measurements are categorized into different groups by different researchers. Cirtita and Glaser-Segura (2012) categorize the supply chain performance metrics as internal linkage performance metrics (e.g., elimination of non-value added activities, decreased variance of orders, more efficient use of time, etc.) and external linkage performance metrics (e.g., creation of end-customer value). Ramanathan et al. (2011) argue that identifying the performance metrics from suppliers' or buyer's viewpoint is indispensable. Chia, Goh, and Hum (2009) develop supply chain performance measurement from a balanced scorecard perspective, including four "balanced" dimensions including financial, customer, internal business processes, and learning and growth.

Based on the literature, we define supply chain performance as the ability of the supply chain to deliver the right product to the right place at the right time at the lowest logistics cost. This definition takes into consideration the lead time, cost, and end-customer value. We believe this definition captures the major benefits of supply chain.

\section{The Research Framework and Propositions}

The purpose of this study is to provide a framework for the Chinese market to examine the relationship between 3PL and supply chain performance. Under supply chain context, when faced by various potential risks, 3PL providers will more likely to invest in information technology, and at the same time build integrated relationship with other supply chain participants. Information technology investment is expected to facilitate information sharing among all the participants, which in turn helps enhance integrated logistics relationship. Information 
technology investment and integrated logistics relationship will lead to logistics flexibility, which will eventually lead to supply chain performance. The research framework is depicted in Figure 1.

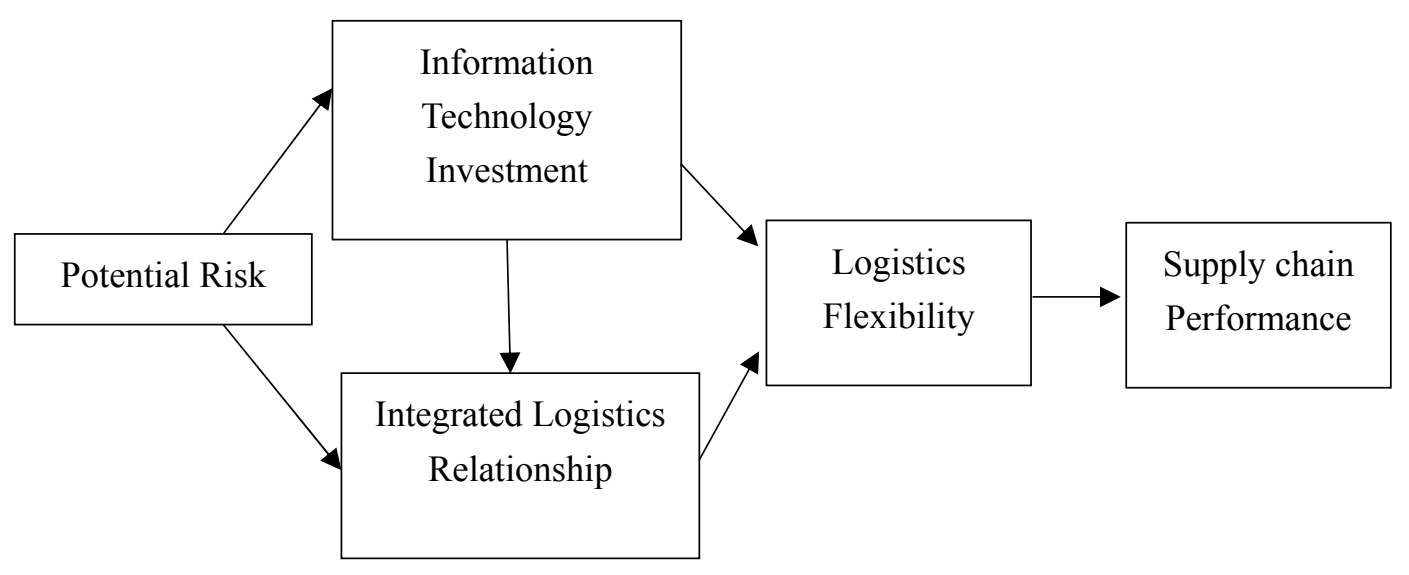

Figure 1. Conceptual framework

\subsection{Potential Risk and IT Investment}

When devastating storms, hurricanes, and other natural disasters strike, they can cause chaos, product shortages, and suffering (Matacunas, 2006). If 3PL providers get accurate weather forecast report in advance, which requires investment in information technology, then they can plan in advance to mitigate their losses. 3PL providers are also faced with information transmission risk and cooperation risk. To mitigate the risks, they make widespread use of cellular phones, laser technologies, electronic chips, internet and satellite positioning to trace their loads (Sauvage, 2003). It follows that 3PL provider with ability to integrate and deploy these technologies could better facilitate information sharing throughout the supply chain. Furthermore, the ability to integrate and deploy information technology can reduce conflicts among various functional areas (Daugherty, Chen, Mattioda, \& Grawe, 2009), which in turn make effective information sharing possible.

Therefore, we propose proposition 1 that as the degree of potential risk increases, the 3PL provider's reliance on the information technology investment also increases.

\subsection{Potential Risk and Integrated Logistics Relationship}

The weather risk can result in supply chain disruption. To mitigate potential weather risk, suppliers, manufacturers, retailers and 3PL providers have to share all the historical demand and supply data to better understand the vulnerability points and their impact in the supply chain, and develop and test contingency plans (Oke \& Gopalakrishnan, 2009). In absence of trust, communication and collaboration among supply chain partners, the mitigation strategies couldn't be fulfilled. The more frequent communication between 3PL providers and other supply chain participants, the less asymmetric information and distorted information exist. This in turn helps to reduce information transmission risk. When faced with coordination risk, 3PL providers may choose to dedicate assets and tailor business process to suppliers, manufacturers and retailers specifically (Devaraj, Vaidyanathan, \& Mishar, 2012). For example, 3PL provider can modify distribution activities to conform with the needs of the manufacturer. According to transaction costs economics, this asset specificity investment tends to promote cooperation among supply chain participants. In addition, trust, communication, and collaboration may signal a healthy integrated logistics relationship between 3PL providers and other supply chain participants. The integration logistics relationship would make the supply chain more agile, responsive, and flexible to react to a dynamic marketplace (Lee, 2002), therefore, help to mitigate the potential risks.

Therefore, we propose proposition 2: that as the degree of potential risk increases, the willingness of supply chain partners to build integrated logistics relationship increases.

\subsection{IT Investment and Integrated Logistics Relationship}

The relationship between IT investment and external collaboration has been assumed by past studies. Some studies have tested the relationship between IT capability and other constructs related to collaboration, such as relationship commitment. For example, Kent and Mentzer (2003) find a strong and positive relationship between 
investment in information technologies and relationship commitment between channel partners. Daugherty et al. (2009) find that the ability to integrate and deploy information technology can reduce conflicts among various functional areas, which in turn make effective information sharing possible. Tian and Daniel (2008) examine the nature of trust in logistics outsourcing relationship in China and indicate that 3PL providers' information sharing has a significant and positive influence on logistics users' trust towards 3PL providers.

The survey result by Third-Party Logistics Study (2014) provides further support to the IT investment. Table 1 shows data regarding a twelve-year view of shippers' (i.e., parties that use 3PL services) opinions on whether they feel information technologies are a necessary element of 3PL expertise, and whether they are satisfied with their 3PL providers' IT capabilities. The difference has become known as the "IT Gap." Over the long run, there has been a modest increase in the percentages of shippers who indicate satisfaction with the IT capabilities of their 3PLs. In fact, it is worth noting that the satisfaction rate has doubled since this question was first asked in 2002. In the meantime, $90 \%$ of shippers report that their relationships with 3PL providers generally have been successful. The shippers and 3PL providers are about equally satisfied with the openness, transparency and good communication in their relationships. It follows that IT gap is negatively associated with integrated relationships. The reduction of "IT gap" can be credited to increasing investment by 3PL providers in IT.

Therefore, we propose proposition 3: that investment in IT is positively associated with integrated logistics relationship.

Table 1. IT gap

\begin{tabular}{llll}
\hline Year & $\begin{array}{l}\text { IT Capabilities } \\
\text { Element of 3PL Expertise }\end{array}$ & $\begin{array}{l}\text { Necessary } \\
\text { Capabilities }\end{array}$ & $\begin{array}{l}\text { Shippers Satisfied with 3PL IT } \\
\text { IT Gap }\end{array}$ \\
\hline 2002 & $89 \%$ & $27 \%$ & $62 \%$ \\
2003 & $85 \%$ & $33 \%$ & $52 \%$ \\
2004 & $91 \%$ & $42 \%$ & $49 \%$ \\
2005 & $90 \%$ & $40 \%$ & $50 \%$ \\
2006 & $92 \%$ & $35 \%$ & $57 \%$ \\
2007 & $92 \%$ & $42 \%$ & $50 \%$ \\
2008 & $92 \%$ & $37 \%$ & $55 \%$ \\
2009 & $88 \%$ & $42 \%$ & $46 \%$ \\
2010 & $94 \%$ & $54 \%$ & $40 \%$ \\
2011 & $93 \%$ & $54 \%$ & $39 \%$ \\
2012 & $94 \%$ & $53 \%$ & $41 \%$ \\
2013 & $98 \%$ & $55 \%$ & $43 \%$ \\
\hline
\end{tabular}

Source: Third-Party Logistics Study (2014), p.14.

\subsection{IT Investment and Logistics Flexibility}

Logistics flexibility requires suppliers, manufacturers and retailers to collaborate with 3PL providers, especially under environmental uncertainty. Information technology facilitates real-time supply chain information sharing among participants, which will help to build logistics flexibility. The information includes but is not limited to inventory level, delivery status, and production planning and scheduling which allows participants to manage and control supply chain activities (Prajogo \& Olhager, 2012). For instance, real-time inventory position provided by information technologies such as GPS could help suppliers to plan their replenishment and delivery schedules to meet the customers' demands in a timely manner (Prajogo \& Olhager, 2012). Information sharing will in turn enhance collaboration among supply chain participants. The constant flow of information and effective collaboration enables 3PL providers to be flexible in their operations, and to be responsive to customer or market demand (Nagarajan et al., 2013). For this reason, the responsiveness could eventually be achieved through increased information sharing between the collaborating organizations (Squire, Cousins, Lawson, \& Brown, 2009). On the other hand, we argue that information technology could lead to logistics flexibility through facilitating high degree and symmetry of strategic-information flows in the supply chain. 
Some studies empirically examine the relationship between IT usage and performance in logistic field. They find that IT usage can improve logistics efficiency, effectiveness and flexibility (Daugherty, Stank, \& Rogers, 1996; Sum, Teo, \& Ng, 2001).

Therefore, we propose proposition 4: that IT investment will lead to logistics flexibility.

\subsection{Integrated Logistics Relationship and Logistics Flexibility}

Exchange of detailed logistic related information between 3PL providers and other participants could help build stronger integrated logistics relationship in terms of trust, communication and collaboration. Collaboration among supply chain participants is necessary to make responsiveness to marketplace movement, thus, create logistics flexibility (Nagarajan et al., 2013). Selnes and Sallis find that integrated relationship can promote learning between customer and supplier, and the learning will identify ways to reduce or remove redundant costs, to improve quality and reliability, and to increase speed and flexibility. Under supply chain context, integrated logistics relationship is advocated as aprerequisite for improvement of logistics performance quality in terms of responsiveness, reliability, timeliness and accuracy (Panayides \& So, 2005). In addition, Swafford, Ghosh, and Murthy (2008) find that use of IT to coordinate and/or integrate activities in supply chain enables a firm to better identify its available options for making decisions related to utilizing its flexibility. We recognize that in practices, there are companies that invest in a very expensive IT but fail to achieve the expected results. As we discussed in the literature section, it is how IT integrated with firm's operations to build an IT-enabled integrated logistics relationship that help to increase logistics flexibility.

Therefore, we propose proposition 5: that integrated logistics relationship will lead to logistics flexibility.

\subsection{Logistics Flexibility and Supply Chain Performance}

In supply chain management literature, logistics flexibility has been widely cited as a means of improving supply chain performance because flexible logistics system features less inventory storage and enables sourcing product from raw materials to finished product on a timely basis (Lummus, Duclos, \& Vokurka, 2003; Liao, 2006). Someempirical studies support the positive link between logistics flexibility and supply chain performance (Sánchez, 2005; Liao, 2006; Fantazy \& Kumar, 2009).

Therfore, we propose proposition 6: that logistics flexiblity will enhance the ability of the supply chain to deliver the right product to the right place at the right time at the lowest logistics cost.

\section{Discussion and Conclusion}

This study provides an original attempt to provide a conceptual framework to enhance supply chain performance via third party logistics inthe Chinese Market. Majority of outstanding 3PL and supply chain management practices take place in the western context, whereas the same practices in the Chinese Market aresomehow limited. Based on extant research conducted in Western context, we come up with a framework addressing how to leverage third-party logistics to improve supply chain performance in the Chinese Market. Although the ideas originated from western context, the framework is expected to be suitable for the Chinese market as logistics companies in Chinese market more or less learn and follow experience from counterparts of the western countries, and at the meantime large international logistics companies such as UPS, FedEx, DHL, and TNT run business in Chinese market (Wang, Zantow, Lai, \& Wang, 2006).

Zhou, Min, Xu, and Cao (2008) gather data from a sample of ten state-owned Chinese 3PLs with five consecutive years of performance measures and find that in contrast with the 3PL industry in the USA, the Chinese 3PL providers tend to focus on traditional service offerings such as port management, transportation, and warehousing rather than playing the role as the integrator or the lead service provider. This study intends to provide 3PL providers in the Chinese Market with better understanding of their role in supply chain, and hopefully they can proactively contact suppliers, manufacturers, and retailers to increase service flexibiltiy, and eventaully enhance supply chain performance.

This study makes some contributions to the literature. The framework which has been built upon an extensive review of the literature, would be beneficial for researchers who are working in the field of Chinese 3PL and supply chain management, and would increase their knowledge of the relationship between 3PL and supply chain performance to a great extent. The framework at the same time could help 3PL providers understand how to deal with potential risk. In other words, if $3 \mathrm{PL}$ providers are facing potential risks, they can invest in information technology and build integrated relationship with other supply chain participants to mitigate the risks and at the same time build logistics flexiblity. Further empirical work is needed to test andvalidate the conceptuallframework proposed in this article. We hope that this framework serves as a starting point and could be tested in future empirical research to validate its applicability in the Chinese market. Future research can 
focus on the quality of information sharing between 3PL providers and other supply chain participants. Future research can also include other dimensions of supply chain flexiblity, such as manufacturing flexibiligy and supply flexibilty, to invesgitae how integrated logistics relationship can enhance supply chain flexibility.

\section{Acknowledgement}

The authors gratefully acknowledge the helpful comments received from anonymous referees, and the participants at the 2013 Decision Science Institute Annual Meeting.

\section{Reference}

Angerhofer, B. J., \& Angelides, M. C. (2006). A model and a performance measuremetn system for collaborative supply chains. Decision Support Systems, 42, 283-301. http://dx.doi.org/10.1016/j.dss.2004.12.005

Berglund, M., van Laarhoven, P., Sharman, G., \& Wandel, S. (1999). Third-party logistics: Is there a future? The $\begin{array}{llll}\text { International Journal of Logistics } & \text { Management, }\end{array}$ http://dx.doi.org/10.1108/09574099910805932

Bharadwaj, A .S. (2000). A resource-based perspective on information technology capability and firm performance: An empirical investigation. MIS Quarterly, 24(1).169-196. http://dx.doi.org/10.2307/3250983

Bowersox, D. J., Closs, D. J., \& Stank, T. P. (1999). 21st Century Logistics: Making Supply Chain Integration a Reality. Chicago, IL: Council of Logistics Management (CLM).

Bowersox, D. J., \& Daugherty, P. J. (1995). Logistics paradigms: The impact of information technology. Journal of Business Logistics, 16(1), 65-80.

Bowersox, D. J., Daugherty, P. J., Droge, C. L., Rogers, D. S., \& Wardlow, D. L. (1989). Leading edge logistics: Competitive positioning for the 1990s. Oak Brook, IL: Council of Logistics Management.

Cavinato, J. L. (2004). Supply chain logistics risks; From the back room to the board room. International Journal of Physical distribution and Logistics management, 34(5), 383-387. http://dx.doi.org/10.1108/09600030410545427

Chia, A., Goh, M., \& Hum, S. (2009). Performance measurement in supply chain entities: Balanced scorecard perspective. Benchmarking: An International Journal, 16(5), 605-620. http://dx.doi.org/10.1108/14635770910987832

Cheng, Q., \& Yu, L. (2010). Operational Mechanism and Evaluation System for Emergency Logistics Risks. International Journal of Intelligent Systems and Applications, 2(2), 25-32. http://dx.doi.org/10.5815/ijisa.2010.02.04

Choy, K. L., Chow, H. K. H., Tan, K. H., Chan, C., Mok, E. C. M., \& Wang, Q. (2008). Leveraging the supply chain flexibility of third party logistics-Hybrid knowledge-based system approach. Expert Systems with Applications, 35(4), 1998-2016. http://dx.doi.org/10.1016/j.eswa.2007.08.084

Chu, Z., \& Wang, Q. (2012). Drivers of relationship quality in logistics outsourcing in China. Journal of Supply Chain Management, 48(3), 78-96. http://dx.doi.org/10.1111/j.1745-493X.2011.03259.x

Cirtita, H., \& Glaser-Segura, D. A. (2012). Measurign downstream supply chain performance. Journal of Manufacturing Technology Management, 23(3), 299-314. http://dx.doi.org/10.1108/17410381211217380

Conference to Explore Importance of Weatherproofing Supply Chains. (2011). Retrieved from http://news.smeal.psu.edu/news-release-archives/2012/march/conference-to-explore-importance-of-weather proofing-supply-chains

Daugherty, P. J., Stank, T. P., \& Rogers, D. S. (1996). Third-party logistics service providers: Purchasers' perceptions. International Journal of Purchasing and Materials Management, 32(2), 23-29. http://dx.doi.org/10.1111/j.1745-493X.1996.tb00222.x

Daugherty, P. J., Chen, H., Mattioda, D. D., \& Grawe, S. J. (2009). Marketing/Logistics Relationships: Influence on Capabilities and Performance. Journal of Business Logistics, 30(1), 1-18. http://dx.doi.org/10.1002/j.2158-1592.2009.tb00096.x

Devaraj, S., Vaidyanathan, G., \& Mishra, A. N. (2012). Effect of Purchase Volume Flexibility and Purchase Mix Flexibility on E-procurement Performance: An Analysis of Two Perspectives. Journal of Operations Management, 30(7-8), 509-520. http://dx.doi.org/10.1016/j.jom.2012.08.001

Duclos, L. K., Vokurka, R. J., \& Lummus, R. R. (2003). A conceptual model of supply chain flexibility. $\begin{array}{llll}\text { Industrial Management and Data } & \text { 446-456. }\end{array}$ 
http://dx.doi.org/10.1002/j.2158-1592.2009.tb00096.x

Fabbe-Costes, N., Jahre, M., \& Roussat, C. (2009). Supply chain integration: The role of logistics service providers. International Journal of Productivity and Performance Management, 58(1), 71-91. http://dx.doi.org/10.1108/17410400910921092

Fantazy, K. A., Kumar, V., \& Kumar, U. (2009). An empirical study of the relationships among strategy, flexiblilty, and performance in the supply chain context. Supply Chain Management, 14(3), 177-188.http://dx.doi.org/10.1108/13598540910954520

Global Logistics Research Team. (1995). World Class Logistics, Council of Logistics Management. Oak Brook, IL: Michigan State University

Golden, W., \& Powell, P. (2000). Towards a definition of flexibility: in search of the Holy Grail. Omega, 28, 373-384. http://dx.doi.org/10.1016/S0305-0483(99)00057-2

Holweg, M., Disney, S., Holmström, J., \& Småros, J. (2005). Supply chain collaboration: Making sense of the strategy continuum. European Management Journal, 23(2), 170-181.

Huo, B., Selen, W., Yeung, J. H. Y., \& Zhao, X. (2008). Understanding drivers of performance in the 3PL industry in Hong Kong. International Journal of Operations and Production Management, 28(8), 722-800. http://dx.doi.org/10.1108/01443570810888607

Jayaram, J., \& Tan, K. (2010). Supply chain integration with third-party logistics providers. International Journal of Production Economics, 125(2), 262-271. http://dx.doi.org/10.1016/j.ijpe.2010.02.014

Kent, J. L., \& Mentzer, J. T. (2003). The Effect of Investment in Interorganizational Information Technology in a Retail Supply Chain, Journal of Business Logistics, 24(2). 155-175. http://dx.doi.org/10.1002/j.2158-1592.2003.tb00050.x

Kumar, P., Shankar, R., \& Yadav, S. S. (2007). Flexibility in global supply chain: A review of perspectives (pp. 377-385). Proceedings of Seventh Global Conference on Flexible System Management (GLOGIFT-07).

Kumar, P., Shankar, R., \& Yadav, S. S. (2008). Flexibility in global supply chain: modeling the enablers. Journal of Modelling in Management, 3(3), 277-297. http://dx.doi.org/10.1108/17465660810920609

Lai, F., Li, D., Wang, Q., \& Zhao, X. (2008). The information technology capability of third-party logistics providers: A resource-based view and empirical evidence from China. Journal of Supply Chain Management, 44(3), 22-38. http://dx.doi.org/10.1111/j.1745-493X.2008.00064.x

Lee, H .L. (2002). Aligning supply chain strategies with product uncertainties. California Management Review, 44(3), 105-119. http://dx.doi.org/10.2307/41166135

Lewis, I., \& Talalayevsky, A. (2000). Third-Party Logistics: Leveraging Information Technology. Journal of Business Logistics, 21(2), 173-185.

Liao, Y. (2006). Supply chain flexibility: The antecedents, driving forces, and impacs on performance (Doctoral disseration). Retrieved form ProQuest Disseration and Thesese. (UMI No. 3264505)

Lummus, R. R., Duclos, L. K., \& Vokurka, R. J. (2003). Supply chain flexibility: Building a new model. Global Journal of Flexible Systems Management, 4(4), 1-13.

Manuj, I., \& Mentzer, J. T. (2008). Global supply chain risk management. Journal of Business Logistics, 29(1), 133-155. http://dx.doi.org/10.1002/j.2158-1592.2008.tb00072.x

Marasco, A. (2008). Third-party logistics: A literature review. International Journal of Production Economics, 113(1), 127-147. http://dx.doi.org/10.1016/j.jpe.2007.05.017

Markowitz, E. (2011). Outsmarting Mother Nature. Retrieved from http://www.inc.com/articles/201103/outsmarting-mother-nature-and-targeting-consumers.html

Matacunas, M. (2006). Weatherproof Your Supply Chain with Information Transparency, Responsiveness. Retrieved from http://www.supplychainbrain.com/content/headline-news/ single-article/article/weatherproof-your-supply-chain-with-information-transparency-responsiveness

Nagarajan, V., Savitskie, K., Ranganathan, S., Sen, S., \& Alexandrov, A. (2013). The effect of environmental uncertainty, information quality, and collaborative logistics on supply chain flexibility of small manufacturing firms in India. Asia Pacific Journal of Marketing and Logistics, 25(5), 784-802. http://dx.doi.org/10.1108/APJML-09-2011-0065 
Naim, M., Aryee, G., \& Potter, A. (2010). Determining a logistics provider's flexibilty capability. International Journal of Production Economics, 127(1), 39-45. http://dx.doi.org/10.1016/j.ijpe.2010.04.011

Oke, A., \& Gopalakrishnan, M. (2009). Managing disruptions in supply chains: A case study of retail supply chain. Internatinal Journal of Production Economics, 118, 168-174. http://dx.doi.org/10.1016/j.ijpe.2008.08.045

Prajogo, D., \& Olhager, J. (2012). Supply chain integration and performance: The effects of long-term relationships, information technology and sharing, and logistics integration. International Journal of Production Economics, 135(1), 514-522. http://dx.doi.org/10.1016/j.ijpe.2011.09.001

Rabinovich, E., Windle, R., Dresner, M., \& Corsi, T. (1999). Outsourcing of integrated logistics functions. International Journal of Physical Distribution and Logistics Management, 29(6), 353-373. http://dx.doi.org/10.1108/09600039910283587

Ramanathan, U., Gunasekaran, A., \& Subramanian, N. (2011). Supply chain collaboration performance metrics: A conceptual framework. Benchmarking: An International Journal, 18(6), 856-872. http://dx.doi.org/10.1108/14635771111180734

Rodrigues, A. M. , Bowersox, D. J., \& calantone, R. J. (2005). Estimation of Global and National Logistic Expenditures: 2002 Data Update. Journal of Business Logistics, 26(2), 1-15. http://dx.doi.org/10.1002/j.2158-1592.2005.tb00202.x

Sánchez, A. M., \& Pérez, M. P. (2005). Supply chain flexibility and firm performance: A conceptual model and empirical study in the aubotmotive industry. International Journal of Operations and Production Management, 25(7/8), 681-700. http://dx.doi.org/10.1108/01443570510605090

Sauvage, T. (2003). The relationship between technology and logistics third-party providers. International Journal of Physical Distribution and Logistics Management, 33(3), 236-253. http://dx.doi.org/10.1108/09600030310471989

Selnes, F., \& Sallis, J. (2003). Promoting Relationship Learning, Journal of Marketing, 67(3), 80-96. http://dx.doi.org/10.1509/jmkg.67.3.80.18656

Squire, B., Cousins, P. D., Lawson, B., \& Brown, S. (2009). The effect of supplier manufacturing capabilities on buyer responsiveness: The role of collaboration. International Journal of Operations and Production Management, 29(8), 766-788. http://dx.doi.org/10.1108/01443570910977689

Stevenson, M., \& Spring, M., (2007). Flexibility from a supply chain perspective: Definition and review. Internatinal Journal of Operations and Production Management, 27(7), 685-713. http://dx.doi.org/10.1108/01443570710756956

Sum, C-C., Teo, C-B., \& Ng, K-K. (2001). Strategic logistics management in Singapore. International Journal of $\begin{array}{llll}\text { Operations and Production } & \text { Management, } & \text { 21(9), }\end{array}$ http://dx.doi.org/10.1108/EUM0000000005926

Swafford, P. M., Ghosh, S., \& Murthy, N., (2008). Achieving supply chain agility through IT integration and flexibility. International Journal of Production Economics, 116(2), 288-297. http://dx.doi.org/10.1016/j.ijpe.2008.09.002

Tezuka, K. (2011). Rationale for utilizing 3PL in supply chain management: A shippers' economic perspective. IATSS Research, 35(1), 24-29. http://dx.doi.org/10.1016/j.iatssr.2011.07.001

Third-party logistics. (2007). The state of logistics outsourcing. Retrieved from http://www.scl.gatech.edu/research/supply-chain/20073PLReport.pdf

Third-party logistic study. (2014). The state of logistics outsourcing. Retrieved from http://www.capgemini.com/resource-file-access/resource/pdf/3pl_study_report_web_version.pdf

Tian Y., Lai, F., \& Daniel, F. (2008). An examination of the nature of trust in logistics outsourcing relationship: Empirical evidence from China. Industrial Management and Data Systems, 108(3), 346-367. http://dx.doi.org/10.1108/02635570810858769

Vaidyanathan, G. (2005). A frame work for evaluating third-party logistics. Communications of the ACM, 48(1), 89-94. http://dx.doi.org/10.1145/1039539.1039544

Wang, Q., Chu, Z., Zhou, Q., \& Lai, F. (2008). A comparative study of third-party logistics in mainland China and Hong Kong. Transportation Journal, 47(3), 48-58. 
Wang, Q., Huo, B., Lai, F., \& Chu, Z. (2010). Understanding performance drivers of third-party logistics providers in mainland China: A replicated and comparative study. Industrial Management and Data Systems, 110(9), 1273-1296. http://dx.doi.org/10.1108/02635571011087392

Wang, Q., Lai, F., \& Zhao, X. (2008). The impact of information technology on the financial performance of third-party logistics firms in China. Supply Chain Management: An International Journal, 13(2), 138-150.http://dx.doi.org/10.1108/13598540810860976

Wang, Q., Zantow, K., Lai, F., \& Wang, X. (2006). Strategic postures of third-party logistics providers in mainland China. International Journal of Physical Distribution and Logistics Management, 36(10), 793-819. http://dx.doi.org/10.1108/09600030610714607

Wang, Y., \& Sang, D. (2005). Multi-agent framework for third party logistics in E-commerce. Expert Systems with Applications, 29(3), 431-436.

Zhao, X., Flynn, B. B., \& Roth, A. V. (2007). Decision sciences research in China: Current status, opportunities and propositions for research in logistics, supply chain management and quality management. Decision Sciences, 38(1), 39-80.http://dx.doi.org/10.1111/j.1540-5915.2007.00148.x

Zheng, M., Fu, C., \& Yang, M. (2012). The application used RFID in Third Party Logistics. Physics Procedia, 25, 2045-2049. http://dx.doi.org/10.1016/j.phpro.2012.03.348

Zhou, G., Min, H., Xu, C., \& Cao, Z. (2008). Evaluating the comparative efficiency of Chinese third-party logisics providers using data envelopment analysis. International Journal of Physical Distribution and Logistics Management, 38(4), 262-279. http://dx.doi.org/10.1108/09600030810875373

\section{Copyrights}

Copyright for this articleis retained by the author(s), with first publication rights granted to the journal.

This is an open-access article distributed under the terms and conditions of the Creative Commons Attribution license (http://creativecommons.org/licenses/by/3.0/). 